\title{
EDITORIAL
}

\section{Glutamate receptors, microtubule associated proteins and developmental anomaly in schizophrenia: an hypothesis ${ }^{1}$}

In recent years much emphasis has been placed on pathological changes in the medial temporal lobe in schizophrenia along with a possible developmental explanation for this. These separate facts give hope to the notion that it may be possible to formulate a mechanism at the biochemical level to explain how a failure of development may bring about these changes, thereby ushering in an era of mechanistic neurochemical research which has been so fruitful to the understanding of pathology in, for example, Alzheimer's disease and Parkinson's disease. The aim of this editorial is to postulate a hypothesis which links developmental abnormalities in intracellular cytoskeletal assembly with pathological and neurotransmitter abnormalities known to occur in schizophrenia. The hypothesis will state that developmental abnormalities seen in the temporal lobe are due to faulty assembly of microtubule associated proteins due to a deficiency of trophic forms of non-N-methyl-D-aspartate (NMDA) receptors, and that the pathological and neurochemical abnormalities seen in the adult temporal lobe in schizophrenia give evidence for this hypothesis.

\section{NEUROPATHOLOGY AND NEURODEVELOPMENT}

There is now little dispute that there are significant pathological abnormalities in the medial temporal lobe in the schizophrenic brain and this is fully reviewed elsewhere (Roberts, 1991), as is the argument for these changes being developmental (Jones \& Murray, 1991). To summarize, Bogerts et al. (1985) found volume reductions in medial temporal lobe structures such as amygdala and hippocampus, and Brown et al. (1986) have found thinning of the parahippocampal gyrus. Falkai \& Bogerts (1986) found cell loss in hippocampal ammons horn. These volume changes can be readily seen on MRI (Suddath et al. 1990). The fact that these are developmental is evidenced by absence of fibrillary gliosis seen in some (Falkai \& Bogerts, 1986, Roberts et al. 1986), but not all (Stevens, 1982) studies of pathological schizophrenic brain material; cytoarchitectonic abnormalities in layer II of entorhinal cortex showing abnormally deep and indiscrete pre-alpha cell clusters suggesting migrational abnormalities (Jakob \& Beckmann, 1989; Falkai et al. 1988); static abnormalities seen on CT studies (O'Callaghan et al. 1988); clinical evidence of developmental disorder in preschizophrenic children (Castle \& Murray, 1991); and epidemiological evidence that prenatal insult, for instance viral infection, may predispose to later schizophrenia in the offspring (O'Callaghan et al. 1991).

\section{NEUROTRANSMITTER ABNORMALITIES AND TROPHIC FUNCTION}

Neural development and regressive pruning are dependent on a range of trophic factors in embryogenesis. The originally described nerve growth factors were proteinaceous and had fairly restricted roles. However, it is now thought that the majority of trophic processes are mediated by embryonic transmitters released from nerve terminals (e.g. Mattson, 1988). It is likely that trophic factor mechanisms are involved in any developmental abnormality and since these are likely to be synaptic neurotransmitters, this begs the question as to whether neurotransmitter abnormalities seen in adult schizophrenic brain represent abnormalities of these neurotransmitters as trophic

${ }^{1}$ Address for correspondence: Dr R. W. Kerwin, Institute of Psychiatry, De Crespigny Park, Denmark Hill, London SE5 8AF. 
factors. The main abnormalities in the medial temporal lobe in schizophrenia are in excitatory amino acid and CCK systems. Deakin et al. (1989) showed low accumulation of $\mathrm{D}-{ }^{3}[\mathrm{H}]$ aspartate in polar temporal cortex and Kerwin et al. $(1988,1990)$ have shown a loss of non-NMDA receptors (kainate, quisqualate) in hippocampus and entorhinal cortex. This loss is accompanied by a loss of the mRNA encoding a region homologous to both kainate and quisqualate receptor genes (Harrison et al. 1991). The agonist recognition site of the NMDA receptor is unchanged in the medial temporal lobe (Kerwin et al. 1990); however, binding to the modulatory channel sites - the sigma/phencyclidine sites - is reduced in schizophrenia. Both Simpson et al. (1990) and Weissmann et al. (1991) have shown losses of sigma binding sites in medial temporal lobe. Studies of cholecystokinin show a reduced content of the peptide itself in hippocampus in schizophrenia (Crow et al. 1982) and this may be associated with negative symptoms (Ferrier et al. 1983). Farmery et al. (1985) have shown a loss of hippocampal CCK receptors in homogenates of hippocampus and this has been confirmed autoradiographically by Kerwin et al. (1992).

What role, then, do the neurotransmitters play in developmental processes in general, and hippocampal development in schizophrenia? This article will focus particularly on excitatory amino acids. The role of excitatory amino acids as trophic factors has been exhaustively reviewed by McDonald \& Johnstone (1990); both NMDA and non-NMDA receptors have protean roles in neurodevelopment. For example, NMDA receptors promote granule-cell survival (Balazs et al. 1988) and non-NMDA receptors promote synaptogenesis (Mattson et al. 1988b). Glutamate stimulates protein synthesis in developing neurones and provokes synaptic maturation (Aruffo et al. 1987). NMDA receptors stimulate neurite outgrowth (Pearce et al. 1987). As for hippocampal development, Mattson et al. $(1988 a, b)$ have demonstrated an important role for non-NMDA receptors in the development of pyramidal cell growth and circuitry. For instance, Mattson $e t$ al. $(1988 a)$ showed that low levels of glutamate produced progressive dendritic growth regulation in cultured hippocampal pyramidal cells from 18-day-old rat foetuses. This effect was blocked by $\gamma$-glutamyl glycine, a non-specific excitatory amino acid (EAA) antagonist, but not by aminophosphonovaleric acid (APV), a specific NMDA antagonist and was mimicked by kainate and quisqualate, suggesting that non-NMDA receptors are of primary importance in this effect. Mattson et al. (1988b) have also found a reduction in dendritic growth in neurons cultured at a distance from axons releasing glutamate, again with a pharmacological profile suggestive of the involvement of non-NMDA receptors.

Thus, there is a body of evidence suggesting a developmental pathology in the medial temporal lobe in schizophrenia as well as evidence for extensive neurochemical abnormalities in excitatory amino acids. In addition, excitatory amino acids play a crucial role in hippocampal development. Are these three facts linked? If so, how? The crucial link here is the fact that the intracellular cytoskeletal elements which mediate glutamate receptor trophisms have recently been found to be abnormal in schizophrenia.

\section{MICROTUBULE ASSOCIATED PROTEINS, GLUTAMATE RECEPTORS AND SCHIZOPHRENIA}

Neuronal growth and maintenance are dependent on microtuble assembly (Nunez, 1986). Immunocytochemical studies allow these processes to be studied since proteins which control tubule assembly are easily identified and form a well characterized family (the microtubule associated proteins (MAPS) and tau: Matus, 1988). It has recently been shown that excitatory amino acids have dramatic influences on the organization and stabilization of neuronal microtubules. In isolated cell culture both microtubule associated protein type 2 (MAP2) and tubulin are diffusely organized, however, following exposure to glutamate these are organized into filaments within the cell body and dendrite (Bigot et al. 1991). Pharmacological studies with agonists and antagonists suggested that both NMDA and non-NMDA receptors could evoke this. No other neurotransmitter or nonionophoric second messenger was capable of producing this effect, suggesting specificity to the glutamate system. These authors propose this as the mechanism for how glutamate 
neurotransmission has profound developmental effects in the maturing brain. It is also known that glutamate trophic receptors can modulate MAP phosphorylation (Aoki \& Siekovitz, 1989). Tau, a family of six polypeptides, is also a member of the MAP family and is involved in microtubule polymerization (Drubin \& Kirschner, 1986). Glutamate stimulation in cell cultures produces a reorganization of tau epitopes with a stronger detection of total tau and the higher molecular weight epitopes (Santiere et al. 1992). Recently it was shown that MAPs are abnormal in schizophrenia. Arnold et al. (1991) with immunohistochemical visualization of a panel of 15 antibodies of cytoskeletal proteins in the hippocampal formation from six patients found abnormal expression in the subicular subfields of $\mathrm{MAP}_{2}$ and $\mathrm{MAP}_{5}$, with no abnormalities of other proteins in this region.

\section{THE HYPOTHESIS}

Thus, it is now possible to propose that the combination of developmental and cytoarchitectonic abnormalities in schizophrenia may have its basis in a cytoskeletal abnormality, namely an abnormality in microtubule assembly. Since excitatory amino acids play a crucial role in microtuble formation via a phosphorylation mechanism and since non-NMDA receptors are markedly reduced in schizophrenia, this may be the underlying trophic abnormality accounting for developmental schizophrenia. It is thus proposed that this is the mechanism whereby glutamate receptor abnormalities can bring about developmental anomaly.

The crucial question is the specificity of this effect, since several epiphenomenonon are likely to arise as a result of temporal pathology. Certainly the MAP abnormality is very specific to MAP $_{2}$, $\mathrm{MAP}_{5}$ and tau, other cytoskeletal components being unaffected in these studies (Arnold et al. 1991). It is primarily, indeed, $\mathrm{MAP}_{2}$ and tau which are influenced by glutamate receptors and this effect is restricted to excitatory amino acids (Bigot et al. 1991).

The main question of specificity lies with the receptor abnormalities in medial temporal lobe in schizophrenia, this being not restricted to glutamate systems. The magnitude and pattern of the glutamate receptor loss however suggests that it is unrelated to a simple cell loss phenomena which is subtle (Roberts, 1991). This suggests that the effect is magnified by a preferential loss of cells which are enriched with glutamate receptors. Indeed, it is the glutamate receptor-rich perforant pathway which is particularly thought to be developmentally abnormal in the cytoarchitectonic studies (Jakob \& Beckmann, 1989). An interesting question also arises as to whether this effect may be produced by developmental underactivity of trophic receptors or overactivity leading to abnormal ontogenetic toxicity. The toxic potential of excitatory amino acids is very well understood (e.g. Choi, 1988). The role of developmental toxicity to bring about neuronal regression and pruning is also now well understood. For instance, the time course of both NMDA and non-NMDA toxicity is well understood in the developing hippocampus, with peak toxicities occurring at specific time points which trigger key developmental processes (see McDonald \& Johnson, 1990). Also, exuberant assembly of MAPs and tau, such as would be postulated to occur following over stimulation with glutamate which leads to damaging precipitates of MAPs (viz. tau, paired helical filaments, and neurofibrillary tangles in Alzheimer's disease). The receptor loss then seen would represent the self destruction of cells containing the glutamate receptors mediating developmental toxicity. An ontogenetic toxicity would also make it possible to identify a possibly trigger, or aetiology, to the train of events. For instance, it is known that developmental hypoxia and other intrauterine trauma produce developmental toxicity mediated by excitatory amino acids in foetal brain (Silverstein et al. 1987). Thus, it may be tempting to postulate that an early obstetric complication (Lewis \& Murray, 1987), or maternal infection or fever (O'Callaghan et al. 1991), may trigger an excitotoxic event (glutamate release) within the developing foetal brain.

\section{TESTABILITY OF THE HYPOTHESIS}

This hypothesis attempts to define a clear single mechanism responsible for development anomaly in schizophrenia, based on experimental data rather than theoretical concepts. How can it be tested 
further? Certainly it is possible to refine further the relevance of the glutamate receptor abnormality. A very large number of glutamate receptors have now been sequenced and cloned and some of the receptors are developmentally specific (Monyer et al. 1991). Thus, it will be possible to test post-mortem material for abnormalities in developmentally relevant receptors. Since the primary action of glutamate on MAPs is to alter phosphorylation, it should be possible to look at phosphorylation status of MAP post-mortem. Since MAPs have also been substantially cloned and sequenced, it will be possible at the single-cell level to study coincident abnormalities of gene expression for both glutamate receptors and MAPs in post-mortem material. Finally, if the abnormal form of glutamate receptor can be very carefully characterized in schizophrenia, it will be possible to look at microtuble assembly in developing hippocampal pyramidal cells in culture and determine if predicted changes in MAP, or tau, can be produced by, for instance, glutamate gene transfection or oligonucleotide neutralization.

\section{CONCLUSION}

A mechanism which links developmental pathology, glutamate receptor abnormalities and MAP abnormalities is postulated. It is proposed that a primary abnormality in glutamate systems leads to a disruption of glutamate dependent microtuble assembly leading to developmental anomaly in the medial temporal lobe. It is specifically proposed that this is an ontogenetic excitotoxic effect, due to excess glutamate release in the developing brain, possibly as a result of intrauterine hypoxia, infection, or other trauma.

ROBERT W. KERWIN

\section{REFERENCES}

Aoki, C. \& Siekovitz, P. (1985). Ontogenetic changes in the cyclic adenosine $3^{\prime} 5^{\prime}$-monophosphate stimulatable phosphorylation of cut visual cortex. Particularly of microtubule associated protein 2 $\left(\mathrm{MAP}_{\mathrm{g}}\right)$. Journal of Neuroscience 5, 2465-2483.

Arnold, S. E., Lee, V. M. Y., Gur, R. E. \& Trojanowski, J. (1991). Abnormal expression of two microtubule associated proteins $\left(\mathrm{MAP}_{2}\right.$ and $\left.\mathrm{MAP}_{5}\right)$ in specific subfields of the hippocampal formation in schizophrenia. Proceedings of the National Academy of Sciences 88, 10850-10854.

Aruffo, C., Ferszt, R., Hildebraudt, A. G. \& Cervos Navarro, J. (1897). Low doses of L-monosodium glutamate promote neuronal growth and differentiation in vitro. Developmental Neuroscience 9 , 228-239.

Balazs, R, Jorgenson, O.S. \& Hack, N. (1988). N-methyl-Daspartate promotes the survival of cerebellar granule cells in culture. Neuroscience 27, 437-451.

Bigot, D., Matus, A. \& Hunt, S. P. (1991). Reorganisation of the cytoskeleton in rat neurons following stimulation with excitatory amino acids in vitro. European Journal of Neuroscience 3, 551-558.

Bogerts, B., Meertz, E. \& Schonfeldt-Bausch, R. (1985). Basal ganglia and limbic system pathology in schizophrenia: a morphometric study of brain volume and shrinkage. Archives of General Psychiarry 42, 784-791.

Brown, R., Colter, N., Corsellis, J. A. N., Crow, T. J., Frith, C. D., Jagoo, R., Johnstone, E. C. \& Marsh, L. (1986). Post-mortem evidence of structural brain changes in schizophrenia: differences in brain weight, temporal horn and parahippocampal gyrus compared with affective disorder. Archives of General Psychiatry 43, 36-42.

Castle, D. \& Murray, R. M. (1991). The neurodevelopmental basis of sex differences in schizophrenia. Psychological Medicine 21, 565-577.

Choi, D. W. (1988). Glutamate neurotoxicity and diseases of the nervous system. Neuron 1, 623-634.
Crow, T. J., Ferrier, I. N., Johnstone, E. C., Pwens, D. G. C., Roberts, G. W., Lee, Y. C., Bloom, S. R. \& Polak, J. M. (1982). Neuroendocrine aspects of schizophrenia. In Neuropeptides: Basic and Clinical Aspects (ed. G. Fink, and L. J. Whalley). pp. 222-239. Churchill, Livingstone: Edinburgh.

Deakin, J. F. W., Slater, P., Simpson, M. D. C., Gilchrist, A. C., Skan, W. J., Royston, M. C., Reynolds, G.P. \& Cross, A. J. (1989). Frontal cortical and left temporal glutamatergic dysfunction in schizophrenia. Journal of Neurochemistry 52, $1781-1786$

Drubin, D. G. \& Kirschner, M. W. (1986). Tau protein function in living cells. Journal of Cell Biology 103, 2739-2746.

Falkai, P. \& Bogerts, B. (1986). Cell loss in the hippocampus of schizophrenics. European Archives of Psychiatry and Neurological Science 236, 154-161.

Falkai, P., Bogerts, B., Roberts, G. W. \& Crow, T. J. (1988). Measurement of the alpha-cell migration in the entorhinal region: a marker for the developmental disturbances in schizophrenia. Schizophrenia Research 1, 157-158.

Farmery, S. P. Q., Owen, F., Poulter, M. \& Crow, T. J. (1985). Reduced high affinity cholecystokinin binding in hippocampus and frontal cortex of schizophrenic patients. Life Science 36, 473-477. Ferrier, I. N., Roberts, G. W., Crow, T. J., Johnstone, E. C., Owens, D. G. C., Lee, Y. C., O'Shaughnessy, D., Adrian, T. E., Polak, J. M. \& Bloom, S. R. (1983). Reduced cholecystokinin line and somatostatin line immunoreactivity in limbic lobe is associated with negative symptoms in schizophrenia. Life Science 33, 475-482.

Harrison, P. J., McLaughlin, D. \& Kerwin, R. W. (1991). Decreased hippocampal expression of a glutamate receptor gene in schizophrenia. Lancet 337, 450-452.

Jakob, H. \& Beckmann, H. (1989). Gross and histological criteria for developmental disorders in brains of schizophrenics. Journal of the Royal Society of Medicine 82, 466-469.

Jones, P. \& Murray, R. M. (1991). Aberrant neurodevelopment as 
the expression of the schizophrenic genotype. In The New Genetics of Mental Illness (ed. P. McGuffin and R. M. Murray). pp. 112-129. Heinemann Medical Books: London.

Kerwin, R. W., Patel, S., Meldrum, B. S., Czudek, C. \& Reynolds, G. P. (1988). Asymmetrical loss of glutamate receptor subtype in left hippocampus in schizophrenia. Lancet i, 583-584.

Kerwin, R. W., Patel, S. \& Meldrum, B. S. (1990). Autoradiographic localization of the glutamate receptor system in control and schizophrenic post-mortem hippocampal formation. Neuroscience 39, 25-32.

Kerwin, R. W., Robinson, P. \& Stephenson, J. (1992). Autoradiographic analysis of cholecystokinin receptors in post-mortem schizophrenic temporal lobe. Psychological Medicine 22, 37-44.

Lewis, S. W. \& Murray, R. M. (1987). Obstetric complications, neurodevelopmental deviance and risk of schizophrenia. Journal of Psychiatric Research 21, 413-421.

McDonald, J. W. \& Johnstone, M. V. (1990). Physiological and pathophysiological roles of excitatory amino acids during central nervous system development. Brain Research Reviews 15, 41-70.

Mattson, M.P. (1988). Neurotransmitters in the regulation of neuronal cytoarchitecture. Brain Research Reviews 13, 179-212.

Mattson, M. P., Lee, R. E., Adams, M. E., Guthrie, P. B. \& Kater, S. B. (1988a). Interactions between entorhinal axons and target hippocampal neurons: a role for glutamate in the development of hippocampal circuitry. Neuron 1, 865-876.

Mattson, M. P., Dou, P. \& Kater, S. B. (1988b). Outgrowth regulating actions of glutamate in isolated hippocampal pyramidal neurones. Journal of Neuroscience 8, 2087-2100.

Matus, A. (1988). Microtuble associated proteins. Their potential role in determining neuronal morphology. Annual Reviews in the Neurosciences 11, 29-44.

Monyer, H., Seeburg, P. \& Wisden, W. (1991). Glutamate operated channels: developmentally early and mature forms arise by alternative splicing. Neuron 6, 799-810.

Nunez, J. (1986). Differential expression of microtubule components during brain development. Developmental Neuroscience 8, 125-141.
O'Callaghan, E., Larkin, C., Redmond, O., Stack, J., Ennis, J. T. \& Waddington, J. L. (1988). Early onset schizophrenia after teenage head injury. British Journal of Psychiatry 158, 764-769.

O'Callaghan, E., Sam, P., Takei, N., Glover, G. \& Murray, R. M. (1991). Schizoprehenia after prenatal exposure to the 1857 influenza A2 epidemic. Lancet 337, 1248-1250.

Pearce, I. A., Cambray-Deakin, M. A. \& Burgoyne, R. D. (1987). Glutamate acting on NMDA receptors stimulates neurite outgrowth from cerebellar granule cells. FEBS Letters 223, 143-147.

Roberts, G. W. (1991). Schizophrenia: a neuropathological perspective. British Journal of Psychiatry 158, 8-17.

Roberts, G. W., Colter, N., Lofthouse, R., Bogerts, B., Zech, N. \& Crow, T. J. (1986). Gliosis in schizophrenia. Biological Psychiatry 21, 1043-1050.

Santiere, P. E., Sindou, P., Couratier, P., Hugon, J., Wattex, A. \& Delacourte, A. (1992). Tau antigenic changes induced by glutamate in rat primary culture model : a biochemical approach. Neuroscience Letters 140, 206-210.

Silverstein, F. S., Tarke, L., Barks, J. \& Johnston, M. V. (1987). Hypoxia-ischemia produces focal disruption of glutamate receptors in developing brain. Developmental Brain Research 34, 33-39.

Simpson, M. D. C., Royston, M. C., Slater, P. \& Deakin, J. F. W. (1990). Phencyclidine and sigma receptor abnormalities in schizophrenic post-mortem brain. Schizophrenia Research 3, 32 (Abst. VB2).

Stevens, J. R. (1982). Neuropathology of schizophrenia. Archives of General Psychiatry 39, 1131-1139.

Suddath, R. L., Christison, G. W., Torrey, E. F. \& Weinberger, D. R. (1990). Cerebral anatomical abnormalities in monozygotic twins discordant for schizophrenia. New England Journal of Medicine 322, 789-794.

Weissmann, A. D., Casanova, M. F., Kleinmann, J. E., London, E. \& Desouza, E. B. (1991). Selective losses of cerebral cortical sigma but not PCP binding sites in schizophrenia. Biological Psychiatry 29, 41-54. 